\title{
Targeted yield precision model assessment for rice-rice crop sequences in farmers' fields in humid, sub-tropical northeastern India
}

\author{
K.N. Das*, A. Basumatary and S. Ahmed \\ *Department of Soil Science, Assam Agricultural University, Jorhat 785013, Assam, India. Corresponding \\ author:daskn388@gmail.com
}

\begin{abstract}
On-farm trials were conducted based on an autumn rice-winter rice crop sequence in 21 farmers' fields from 2012-2014 in humid, sub-tropical northeastern India i) to verify the suitability of the formulated appropriate site-specific target yield-based fertilizer prescription models over available technology and ii) to analyze the economics of the adoption of these models to enhance the productivity and profitability of rice-rice crop sequences. The results revealed that treatments based on the targeted yield precision model with and without integrated plant nutrient supply (IPNS) components ensured higher grain yield, additional yield gains and additional net profits over the farmers' practice and conventional fertilizer recommendations. The achievements of the prefixed targets were $>100 \%$ in autumn rice and 96 to $106 \%$ in winter rice. The IPNS treatments guaranteed a better a benefit: cost ratio (1.7 to 2.3 ) vis-a-vis without IPNS. The targeted yield precision model for fertilizer recommendations was more precise to achieve the targeted yields, which additionally led to higher profits. The targeted yield approach was effective up to 4.0 and 5.0 tons ha ${ }^{-1}$ yield targets without IPNS in autumn rice and with IPNS in winter rice, respectively, in humid sub-tropical northeastern India.
\end{abstract}

Keywords: Autumn rice, winter rice, fertilizer recommendations, targeted yield, IPNS

\section{Introduction}

Sustainable, high yield agriculture is India's topmost agenda for food security, profitability and environmental safety. However, most, if not all, farming strategies must be refined to sustain productivity and prevent the ever-increasing problems related to soil fertility deterioration. Fertilizer is one of the costliest inputs in agriculture, and the use of right amount of fertilizer is fundamental for farm profitability and environmental protection.
Information on the optimum doses of fertilizer for crops is essential to enhance farm profitability under different soil-climate conditions. Because of increasing input costs and decreasing commodity prices, the farmers are currently looking for new ways to increase efficiency and cut costs. According to Dobermann et al. (2003), the decision on fertilizer use requires knowledge of the expected crop yield in response to the nutrient application, 
which is a function of crop nutrient needs, the supply of nutrients from indigenous sources, and the fate of the fertilizer applied. Rice fulfils 43 percent of the caloric requirement for more than 70 percent of the Indian population. To meet the demands of increasing population and to maintain self-sufficiency, the present production level of 102 million tons must be increased to 125 million tons by the year 2020. This rate of increase signifies the contribution of fertilizers to the production of rice to meet the food requirements of the hungry mouths of the country. However, an annual net negative balance of approximately 10 million tons of nutrients is currently reported in India. The loss of major nutrients can be high in rice fields, particularly rain-fed rice, where water flowing from field to field during periods of high rainfall not only reduces the nutrient use efficiency but can also degrade the environment (Kapoor et al. 2008). This shift in soil fertility and deterioration in soil health is further aggravated by indiscriminate and imbalanced fertilization of N, P and K and it can only be corrected with a proper manure-fertilizer schedule based on a soil fertility evaluation (Santhi et al. 2011). To realize higher response and benefit:cost ratios, the soil testbased application of plant nutrients is inevitable, allowing the nutrients to be applied in proportion to the magnitude of the deficiency of a particular nutrient. Correcting the nutrient imbalance in the soil helps to harness the synergistic effects of balanced fertilization. Many researchers have prescribed fieldspecific balanced amounts of N, P, K and based on the crop-based estimates of the indigenous supply of these nutrients and by modelling the expected yield response as a function of nutrient interaction (Dobermann and White 1999; Witt et al. 1999; Bera et al. 2006; Jai Paul et al. 2011; Singh et al. 2014; Regar and Singh 2014). Site-specific nutrient management considers the indigenous nutrient supply of the soil, productivity targets that are capable of sustained high yields, and how to restore soil fertility. With this approach, the present food grain production could be achieved.

Rice (Oryza sativa L.) is the most important food grain in India and contributes $41.5 \%$ to the total food grain production. Rice, which is at present grown mainly during the kharif seasons, dominates the agriculture scenario in Assam; winter (Sali) rice occupies 1.749 million hectares, and autumn (Ahu) rice occupies 0.464 million hectares with a productivity of $1674 \mathrm{~kg}$ / ha compared with the national average of $2240 \mathrm{~kg} / \mathrm{ha}$. One reason for lower productivity of rice in the state is the imbalanced application of $\mathrm{N}, \mathrm{P}$ and $\mathrm{K}$ nutrients. The high cost of fertilizers remains a constraint for the farmers that prevents them from applying adequate amount of fertilizers to their crop. Of the total cultivable area of Assam, Inceptisols occupy approximately $49.3 \%$, are mostly acidic and contain high amounts of $\mathrm{Fe}$ and $\mathrm{Al}$ oxides and hydroxides. Fixation of applied $\mathrm{P}$ by these oxides and hydroxides is a common problem that hinders the uptake of $\mathrm{P}$ by crops, with consequent nutrient imbalances. However, Yin and Liang (2013) reported that applying organic fertilizer could increase the content of the phosphorus fractions of paddy soil and in presence of microorganisms Al-P and $\mathrm{Ca}-\mathrm{P}$ could be transformed into moderately labile organic phosphorus. Awareness among farmers of the appropriate $\mathrm{N}, \mathrm{P}$ and $\mathrm{K}$ application rates for rice in such soils is critical to improve productivity. Thus, the present investigation was performed in farmers' fields i) to verify the suitability of the formulated appropriate site-specific target yield-based fertilizer prescription models over available technology and ii) to analyze the economics of these models for their adoption to enhance productivity and profitability in rice-rice crop sequences. 


\section{Materials and Methods}

\subsection{Details of the experimental sites}

Field experiments were conducted at the Instructional Cum Research Farm (ICRF) of Assam Agricultural University (latitude $26^{\circ} 48 \propto \mathrm{N}$ and longitude of $\left.95^{\circ} 50 \notin \mathrm{E}\right)$, Jorhat, India to develop targeted yield fertilizer recommendation equations for autumn and winter rice. The soil at the ICRF was 'Aeric Haplaquept' with $\mathrm{pH}$ 5.1, organic carbon $6 \mathrm{~g} \mathrm{~kg}^{-1}$ soil, sandy clay loam in texture, and it had 2133, 359 and $1083 \mathrm{Mg} \mathrm{ha}^{-1}$ of $\mathrm{N}, \mathrm{P}_{2} \mathrm{O}_{5}$, and $\mathrm{K}_{2} \mathrm{O}$, respectively, available. The $\mathrm{P}$ and $\mathrm{K}$ fixing capacities of the soil were 145.6 and $224.0 \mathrm{~kg} \mathrm{ha}^{-1}$, respectively.

\subsection{Development of a targeted yield precision} fertilizer recommendation model

To develop targeted yield fertilizer recommendations models, an operational range of variation in soil fertility was created artificially by dividing the experimental field into four equal strips. The first strip received no fertilizer $\left(\mathrm{N}_{0} \mathrm{P}_{0} \mathrm{~K}_{0}\right)$; the second, third and fourth strips received half $\left(\mathrm{N}_{1 / 2} \mathrm{P}_{1 / 2} \mathrm{~K}_{1 / 2}\right)$, one $\left(\mathrm{N}_{1} \mathrm{P}_{1} \mathrm{~K}_{1}\right)$ and two $\left(\mathrm{N}_{2} \mathrm{P}_{2} \mathrm{~K}_{2}\right)$ times the standard dose of $\mathrm{N}, \mathrm{P}_{2} \mathrm{O}_{5}$ and $\mathrm{K}_{2} \mathrm{O}$, respectively. The recommended fertilizers $\left(\mathrm{N}_{1} \mathrm{P}_{1} \mathrm{~K}_{1}\right)$ were 60,20 and $40 \mathrm{~kg} \mathrm{ha}^{-1}$ of $\mathrm{N}, \mathrm{P}_{2} \mathrm{O}_{5}$ and $\mathrm{K}_{2} \mathrm{O}$, respectively. An exhaust crop of rice cv. Ranjit was then raised on these four strips to stabilize the soil system. After the exhaust crop was harvested, the experiments on test crops autumn rice (cv. Luit) in rabi (dry season) and winter rice (cv. Ranjit) in kharif (wet season), in sequence, were conducted during the subsequent season by dividing each of the four fertility strips into 24 plots that received 20 required treatments of the combinations of five levels of nitrogen $\left(0,30,60,90\right.$ and $\left.120 \mathrm{~N} \mathrm{~kg} \mathrm{ha}^{-1}\right)$, and four levels of phosphorus $\left(0,30,60\right.$ and $\left.90 \mathrm{P}_{2} \mathrm{O}_{5} \mathrm{~kg} \mathrm{ha}^{-1}\right)$, three levels of potassium $\left(0,60\right.$ and $\left.120 \mathrm{~K}_{2} \mathrm{O} \mathrm{kg} \mathrm{ha}^{-1}\right)$ and four levels of farmyard manure $(0,2.5,5$ and $10 \mathrm{t}$ $\left.\mathrm{ha}^{-1}\right)$. The remaining four plots in each strip were left as controls (Ramamoorthy and Velayutham 1971). Nitrogen, phosphorus, and potassium were applied as urea $(46 \% \mathrm{~N})$, single superphosphate $\left(16 \% \mathrm{P}_{2} \mathrm{O}_{5}\right)$, and muriate of potash $\left(60 \% \mathrm{~K}_{2} \mathrm{O}\right)$, respectively. The whole amounts of $\mathrm{P}$ and $\mathrm{K}$ and half of $\mathrm{N}$ were applied basally during transplanting, while the remaining half $\mathrm{N}$ was applied in two equal portions at tillering and panicle initiation of the rice. The moisture, N, $\mathrm{P}$ and $\mathrm{K}$ contents of the applied FYM were $20 \%, 0.60$, 0.37 and $0.55 \%$, respectively. Representative soil samples $(0-15 \mathrm{~cm})$ were collected from each of the 96 plots before the fertilizers were applied and the crops were transplanted. The yield data of grain and straw for all the plots were recorded at harvest. Grain and straw samples were analyzed for N, P and K content by the standard procedures of Jackson (1973) to calculate the respective total nutrient uptake. Similarly, soil reaction $(\mathrm{pH})$ was measured in a 1:2.5 soil/water suspension using a glass electrode $\mathrm{pH}$ meter (Jackson 1973). Available N was determined by alkaline permanganate method (Subbiah and Asija 1956), available P by Bray's-I method (Bray and Curtz, 1945), and available K was determined by the neutral normal ammonium acetate extraction method (AOAC, 1970). With the help of the nutrient uptake data and soil test values, the basic data (nutrient requirement in $\mathrm{kg}$ per $100 \mathrm{~kg}$ of grain and the percent contributions of a particular nutrient from the soil and the applied fertilizers) required for making target yield-based fertilizer recommendations for a rice-rice system were computed according to the procedure of Ramamoorthy et al. (1967) and Katharine et al. (2013) as follows: 


\section{i) Nutrient requirement (NR):}

$\mathrm{kg}$ of $\mathrm{N} / \mathrm{P}_{2} \mathrm{O}_{5} / \mathrm{K}_{2} \mathrm{O}$ required per quintal $(100 \mathrm{~kg})$ of grain production, expressed in $\left(\mathrm{kg} \mathrm{q}^{-1}\right)$.

$\mathrm{NR}=\left(\right.$ Total uptake of $\mathrm{N}, \mathrm{P}_{2} \mathrm{O}_{5}$ or $\left.\mathrm{K}_{2} \mathrm{O}\left(\mathrm{kg} \mathrm{ha}^{-1}\right)\right) /$ grain yield $\left(\mathrm{q} \mathrm{ha}^{-1}\right)(1)$

\section{ii) Per cent contribution of nutrients from the soil} to total nutrient uptake (Cs):

$\mathrm{Cs}=\left(\left(\right.\right.$ Total uptake of $\mathrm{N}, \mathrm{P}_{2} \mathrm{O}_{5}$ or $\mathrm{K}_{2} \mathrm{O}$ in the control plot $\left.\left(\mathrm{kg} \mathrm{ha}^{-1}\right)\right)$ / (Soil test value for available $\mathrm{N}, \mathrm{P}_{2} \mathrm{O}_{5}$ or $\mathrm{K}_{2} \mathrm{O}$ in the control plot $\left.\left.\left(\mathrm{kg} \mathrm{ha}^{-1}\right)\right)\right) \times 100$ (2)

iii) Per cent contribution of nutrients from the fertilizer to the total uptake (Cf):

$\mathrm{Cf}=\left(\left(\left(\right.\right.\right.$ Total uptake of $\mathrm{N}_{2} \mathrm{P}_{2} \mathrm{O}_{5}$ or $\mathrm{K}_{2} \mathrm{O}$ in the treated plot $\left.\left(\mathrm{kg} \mathrm{ha}^{-1}\right)\right)-\left(\right.$ Soil test value for available $\mathrm{N}, \mathrm{P}_{2} \mathrm{O}_{5}$ or $\mathrm{K}_{2} \mathrm{O}$ in the control plot $\left(\mathrm{kg} \mathrm{ha}^{-1}\right) \times$ Average Cs)) / Fertilizer $\mathrm{N}_{2} \mathrm{P}_{2} \mathrm{O}_{5}$ or $\mathrm{K}_{2} \mathrm{O}$ applied $\left.\left(\mathrm{kg} \mathrm{ha}^{-1}\right)\right)$ x 100 (3)

\section{iv) Percent contribution from farm yard manure} (FYM (Cfym)):

Cfym $=((($ Total uptake of N, P or K in the FYMtreated plot $\left.\left(\mathrm{kg} \mathrm{ha}^{-1}\right)\right)$ - (Soil test value for available $\mathrm{N}, \mathrm{P}$ or $\mathrm{K}$ in the FYM-treated plot $\left(\mathrm{kg} \mathrm{ha}^{-1}\right) \mathrm{x}$ Average Cs)) / Nutrient N/P/K added through FYM $\left(\mathrm{kg} \mathrm{ha}^{-1}\right)$ ) x 100 (4)

These parameters were then used to formulate workable fertilizer adjustment equations to calculate fertilizer doses for any yield target based on the initial soil test values. A fractional factorial design was used to analyze autumn rice and winter rice as per the standard procedure for soil-test crop response (STCR) correlation studies (Singh et al. 2014). Using a fractional factorial design, the data were analyzed using yield data as the dependent variable and soil available nutrients, nutrient uptake, fertilizer nutrients, and interactions between soil and fertilizer nutrient as the independent variables (Singh et al. 2014).

\subsection{Validation of the targeted yield precision fertilizer recommendation model}

To popularize the prescription-based fertilizer recommendations based on fertilizer adjustment equations among the farmers, the developed fertilizer adjustment equations were validated by conducting 21 frontline demonstrations, which were replicated thrice at each location at the farmers' fields in humid, sub-tropical (Upper Brahmaputra Valley, Assam) northeastern India on rice (autumn rice) - rice (winter rice) sequence during the winter (Rabi) and rainy (Kharif) seasons of the years 2012 and 2013. Of 21 demonstrations, 8 were conducted on autumn rice, and 13 were conducted on winter rice. The autumn and winter rice were transplanted in the first week of April and the fourth week of July, respectively. These experiments were laid out in a complete randomized block design on alluvial Inceptisols with six treatment combinations, viz., i) farmers' practice, ii) state-recommended dose, iii) yield target of $30 \mathrm{q} /$ ha with chemical fertilizers, iv) yield target of $40 \mathrm{q} /$ ha with chemical fertilizers, v) yield target of $30 \mathrm{q} /$ ha with an IPNS component and vi) yield target of $40 \mathrm{q} / \mathrm{ha}$ with an IPNS component in autumn rice. The corresponding treatments for winter rice were i) farmers' practice, ii) state-recommended dose, iii) yield target of $50 \mathrm{q} / \mathrm{ha}$ with chemical fertilizers, iv) yield target of $60 \mathrm{q} / \mathrm{ha}$ with chemical fertilizers, v) yield target of $50 \mathrm{q} /$ ha with an IPNS component and vi) yield target of $60 \mathrm{q} / \mathrm{ha}$ with an IPNS component. Farm yard manure (FYM)@ 5 t/ha was used as the IPNS component for the last two treatments in both crops. Fertilizers for N, P and K were adjusted based on the soil test value and the chemical analysis of the 
FYM. Each treatment was conducted in a $1333 \mathrm{~m}^{2}$ area with three replications each. Both rice harvests were cultivated as mentioned in the previous section. At harvest, the yield of each treatment in each crop was recorded precisely; then, the respective economic analysis of each treatment was worked out. The average values for each crop are given in this article to avoid presenting the voluminous data generated in each season for each crop.

\section{Results and Discussion}

\subsection{Development of targeted yield precision fertilizer recommendation model in rice}

The present investigation revealed that the amount of nutrients required for producing $100 \mathrm{~kg}$ of autumn and winter rice were 2.39 and $1.82 \mathrm{~kg} \mathrm{~N}, 0.84$ and $0.33 \mathrm{~kg}$ $\mathrm{P}_{2} \mathrm{O}_{5}$, and 2.25 and $1.94 \mathrm{~kg} \mathrm{~K}_{2} \mathrm{O}$, respectively (Table $3)$. At a given yield level, the nutrient requirements in autumn rice are far greater for $\mathrm{N}, \mathrm{P}_{2} \mathrm{O}_{5}$, and $\mathrm{K}_{2} \mathrm{O}$ than winter rice, suggesting that autumn rice requires more nutrients to overcome the inherent stress encountered during the growing period. The effect was more pronounced for $\mathrm{N}$ uptake. This increase might be due to differences in the fields with respect to the duration and number of wetting and drying cycles in any given growing season because of differences in field position along a toposequence (Wade et al. 1998), which in turn could affect $\mathrm{N}$ mineralization, $\mathrm{N}$ loss and subsequently N uptake (Buresh and De Datta 1991; Linquist and Sengxua 2003).

The contribution of $\mathrm{N}$ from the soil was $15.5 \%$ and $28.5 \%$ to autumn and winter rice, respectively. The corresponding contributions of $\mathrm{N}$ from fertilizer to these crops were $35.3 \%$ and $42.3 \%$ (Table 3 ). Linquist and Sengxua (2003) indicated that rice normally takes up less than $40 \%$ of applied $\mathrm{N}$ in flooded systems.
This low efficiency results from $\mathrm{NH}_{3}$ volatilization, denitrification, leaching and runoff (Schnier 1995). In the rain-fed lowland environment, the duration of the flooded and non-flooded periods and the transition from aerobic to anaerobic phases have a large effect on the accumulation and dissipation of soil mineral N (Buresh and De Datta 1991; Wade et al. 1999; Linquist and Sengxua 2003). Losses from denitrification occur because the $\mathrm{NO}_{3}$ that accumulates during the aerobic phase is lost in the transition to the anaerobic phase (Wade et al. 1998). Alfaro et al. (2006) in a lysimeter study observed that nitrogen was mainly lost as nitrate and NO (each was $49 \%$ of the total $\mathrm{N}$ losses). In contrast, the comparatively high efficiency of $\mathrm{N}$ usage from the soil in winter rice is attributable to the favorable temperature regime of soil during kharif season, which might have facilitated superior conditions for $\mathrm{N}$ mineralization. Further, the estimated $\mathrm{Cf}$ for fertilizer $\mathrm{N}$ was greater than that of $\mathrm{Cs}$ for soil $\mathrm{N}$. The split application of $\mathrm{N}$ at the critical stages of crop growth might have resulted in a higher percent contribution from the fertilizer source (Gayathri et al. 2009). As estimated from the soil and fertilizer sources, the respective contributions of $\mathrm{P}_{2} \mathrm{O}_{5}$ to autumn rice were $17 \%$ and $28.8 \%$ and to winter rice were $46.2 \%$ and $21.2 \%$ (Table 3 ). These results indicate that the nutrient contribution from the fertilizer sources was greater than that from the soil source in autumn rice but was the reverse in winter rice. The higher efficiency of soil $\mathrm{P}_{2} \mathrm{O}_{5}$ in comparison to the added $\mathrm{P}_{2} \mathrm{O}_{5}$ in winter rice was due to the effect of continuous submergence during the growing period, with a subsequent increase in $\mathrm{pH}$ due to reduction of these acid soils. In turn, the increased $\mathrm{pH}$ increased the solubility of the phosphate compound in the soil (Ponnamperuma 1972). The increase in concentration of water-soluble $P$ when the acidic soils are submerged results from a reduction of $\mathrm{Fe}(\mathrm{III})$ 
phosphates, hydrolysis, the dissolution of $\mathrm{Fe}$ and $\mathrm{Al}$ phosphates, and release of clay-associated phosphates (Ponnamperuma 1972; Baldwin and Mitchell 2000; Chacon et al. 2005). Abolfazli et al. (2012) reported that in acidic soil, significant amounts of $\mathrm{P}$ were found in Fe-P and reductant soluble-P fractions.

The respective contributions of $\mathrm{K}_{2} \mathrm{O}$ were 26.6 and $65.4 \%$ from the soil and 49.1 and $51.5 \%$ were fertilizer to autumn and winter rice (Table 3 ). The comparatively higher efficiency of soil $\mathrm{K}_{2} \mathrm{O}$ in winter rice may be attributed to the interaction effect of higher doses of $\mathrm{N}$ and $\mathrm{P}$ and the primary effect of starter $\mathrm{K}$ doses in the treated plots, which might have caused the release of soil potassium, resulting in higher uptake from the native soil sources by the crop (Ray et al. 2000; Bera et al. 2006). A similar high efficiency of potassic fertilizer was also reported for rice by Ahmed et al. (2002) in alluvial soil and for jute by Ray et al. (2000) in Inceptisols. In general, the results indicated that the percent contribution of nutrients from the fertilizer sources was also different for autumn and winter rice (Table 3). This difference might be due to variations in rooting habit and the intensity of the metabolic activity involved in the relative specificity and active absorption of nutrients. Similar results were also reported by Santhi et al. (1999) for rice-rice-pulse cropping sequence on Inceptisols. The mean yield of rice was significantly correlated with the uptake of all the nutrients in both crops (Figures 1-2). Potassium correlated most with grain yield, with an $\mathrm{R}^{2}=0.955$ $\mathrm{P}=0.01$ and $0.748 \mathrm{P}=0.01$ in autumn and winter rice, respectively. This finding suggests the interdependence of the uptake of a particular nutrient on the other applied nutrients, which ultimately influences yield. Such a high correlation between the yield and uptake of nutrients corroborates the importance of soil testbased nutrient application in rice. The yield data were also significantly correlated with the available NPK in the soil, signifying their positive contribution toward yield (Figures 3-4). Significant $\mathrm{R}^{2}$ values (0.804 $\mathrm{P}=0.01,0.677 \mathrm{P}=0.01$ and $0.792 \mathrm{P}=0.01$ for the available NPK, respectively, in autumn rice and 0.623 $\mathrm{P}=0.01,0.597 \mathrm{P}=0.01$ and $0.486 \mathrm{P}=0.01$, respectively, in winter rice) were observed between the yield and soil test values in both crops. A high $\mathrm{R}^{2}$ between yield and soil test values was observed by Bhaduri and Gautam (2013) in wheat.

To evaluate the extent to which the fertilizer requirements of rice can be reduced by incorporating an IPNS component, the contribution of nutrients from FYM was quantified. The percent contribution of $\mathrm{N}_{2} \mathrm{P}_{2} \mathrm{O}_{5}$ and $\mathrm{K}_{2} \mathrm{O}$ from FYM (Cfym) were 6.8, 4.7 and 7.8 for the autumn rice and 9.9, 2.7 and 12.2 for the winter rice, respectively, and a relatively higher contribution was recorded for $\mathrm{K}_{2} \mathrm{O}$ followed by $\mathrm{N}$ and $\mathrm{P}_{2} \mathrm{O}_{5}$. The present findings corroborated with the findings of Saranya et al. (2012).

To calculate the fertilizer requirements for each yield target on the basis of the initial soil test values, the basic data were used to formulate simplified fertilizer adjustment equations under NPK alone with IPNS. These equations for autumn and winter rice are presented in Table 3. The range and average initial soil test values $\left(\mathrm{kg} \mathrm{ha}^{-1}\right)$ before the start of the demonstrations on autumn rice (2012 and 2013) and winter rice (2012 and 2013) are presented in Table 1. The low soil organic carbon in the experimental fields may be due to warmer temperatures and higher rainfall in the region, which led to greater biological activity and faster decomposition of organic matter (Linquist and Sengxua 2003). Based on the respective values, the fertilizer doses for the different treatments were calculated for yield targets utilizing the fertilizer adjustment equations (Table 2). 


\subsection{Validation and economic analysis of precision models}

Economics is the dominant factor that influences the adoption of production technology. The results on validation and economic analysis of targeted yield precision fertilizer recommendation models for both autumn and winter rice are presented in Table 2. The data on multi-location experiments clearly revealed that the fertilizer $\mathrm{N}, \mathrm{P}_{2} \mathrm{O}_{5}$, and $\mathrm{K}_{2} \mathrm{O}$ requirements decreased with increases in the soil test values. Across all options, rice grown with the targeted yield model-based treatments consistently produced a grain yield that exceeded the target compared with other treatments. In autumn rice, inorganic treatments under the target yields of 3.0 and 4.0 tons ha $^{-1}$ ensured $102 \%$ and $101 \%$ of the target grain yield (Table 2). This increase was enhanced further by the application of an IPNS component, producing 3.16 and $4.23 \mathrm{t}$ $\mathrm{ha}^{-1}$ grain yield under targets of 3.0 and 4.0 tons ha ${ }^{-1}$ (with IPNS component), respectively, corresponding to $105 \%$ and $106 \%$ achievements (Ghosh and Sharma 1999). The corresponding values in winter rice were $101 \%$ and $96 \%$ under the target yield of 5.0 tons $\mathrm{ha}^{-1}$ and $106 \%$ and $98 \%$ under the target yield of 6.0 tons $\mathrm{ha}^{-1}$ without and with IPNS, respectively. In the humid, sub-tropical climate, the fertilizer adjustment equations for autumn and winter rice work effectively up to 4.0 and 5.0 tons $\mathrm{ha}^{-1}$ both with and without the IPNS component. In all sites, the grain yields of rice based on the state recommendations lagged behind the yield obtained at the 3.0 and 4.0 tons ha ${ }^{-1}$ yield target both with and without the IPNS and proved to be superior to the farmers' practice (Table 2). These results were in close agreement with the findings of Ray et al. (2000) and Bera et al. (2006). Despite the low fertilizer doses under the targeted yield treatments for 3.0 and 5.0 tons $\mathrm{ha}^{-1}$ in autumn and winter rice, respectively, this treatment produced higher yields relative to the other treatments, which indicates that fertilizer doses under targeted yield treatments are highly precise and at the correct balance compared with other treatments. Conversely, the targeted yield treatments for 4.0 tons and 6.0 tons ha ${ }^{-1}$ in autumn and winter rice, respectively, required higher dose of fertilizer compared with the state recommendation, with increases of 2.2 times for $\mathrm{N}, 2.65$ for $\mathrm{P}_{2} \mathrm{O}_{5}$ and 2.85 times for $\mathrm{K}_{2} \mathrm{O}$ in autumn rice and respective increases of 2.08, 2.55 and 2.65 times with IPNS (Table 2). The respective corresponding values for winter rice were 1.67, 3.15 and 1.85 times without IPNS and 1.45, 3.05 and 1.68 times with IPNS. Based on the soil test values, the results clearly suggest that the doses of NPK fertilizers as per the state recommendation for higher yield targets beyond 3.0 tons and 5.0 tons $\mathrm{ha}^{-1}$ for autumn and winter rice, respectively, were not sufficient to obtain the desired yield level. This finding highlights the importance of using the formulated fertilizer prescription models (Table 3) to determine the precise and correctly balanced fertilizer doses for higher yield targets. Under yield targets of 3.0 and 5.0 tons $\mathrm{ha}^{-1}$ for both crops, the doses of nitrogen were respectively reduced by 1.9 and 2.5 times without IPNS and 3.2 and 3.8 times with IPNS compared with the state recommendation.

Similarly, the doses of potassium were remarkably low under the yield targets of 3.0 and 5.0 tons $\mathrm{ha}^{-1}$ for autumn and winter rice, respectively, by 1.8 and 2.5 times without IPNS and 1.1 and 1.4 times with IPNS treatments, respectively, compared with the state recommendation (Table 2). In contrast, the doses of phosphorus were always higher in both crops irrespective for all treatments other than the state recommendation level. Thus, these treatments might have created the optimum balance among nitrogen, phosphorus and potassium, resulting in higher yields. 
Jai Paul et al. (2011) reported similar results in rain-fed soybean. Importantly, the state recommendation dose for $\mathrm{P}_{2} \mathrm{O}_{5}\left(20 \mathrm{~kg} \mathrm{ha}^{-1}\right)$ for both crops was inadequate even for the lower yield targets, and these doses require revision to supply the correct dose.

The economics of autumn and winter rice in Table 2 revealed that the yield advantage in yield under various treatments over the farmers' practice varied from 0.63 to 2.62 and from 1.03 to 3.41 tons $\mathrm{ha}^{-1}$, respectively. The corresponding percent yield increase was from $39 \%$ to $162 \%$ and from 44 to $147 \%$, respectively. The yield advantage and percent yield increases in autumn rice and winter rice were greatest under the treatment with targeted yields of 4.0 and 6.0 tons $\mathrm{ha}^{-1}$ with an IPNS component, respectively, whereas they were lowest under the state recommendation in both cases. Additional profits varied from Rs. 7572 to 31392 in autumn rice (Table 2); the profits were highest under the yield target of 4 tons $\mathrm{ha}^{-1}$ with IPNS and were lowest under the state recommendation. Similarly, the profits varied from 12360 to 42480 in winter rice, with the highest profit under yield target of 6.0 tons ha ${ }^{-1}$ with IPNS and the lowest under the state recommendation. Subsequently, the production economics also determined that IPNS was more profitable, deriving a maximum benefit: cost ratio of 1.8 with a yield target of 3.0 tons ha ${ }^{-1}$ compared with the state recommendation (1.4) and the other three targeted yield treatments owing to the reduced fertilizer application and cost (Suri et al. 2005) in the autumn rice (Table 2). The benefit:cost (B:C) ratio in winter rice was generally better than in autumn rice. However, the ratio in winter rice was highest under yield target of 5.0 tons $\mathrm{ha}^{-1}$ with IPNS components
(2.3) and decreased with increasing yield target due to the increasing dose of fertilizers and, thus, the increasing fertilizer cost. IPNS might have promoted nutrient utilization, accounting for better NPK uptake and NPK productivity in rice. Under state recommendation and farmers' practice, comparatively low yields and high cost of applied fertilizers resulted in low B:C ratios over the targeted yield treatments. Thus, the targeted yield fertilizer recommendations were superior to the state recommendation dose with regard to yields and economic analysis.

\section{Conclusions}

In the present investigation, soil test-based fertilizer prescription models for the rice-rice sequences were developed on the alluvial soil Aeric Haplaquept when considering the nutrient requirements and the contributions of NPK from the nutrient sources (soil, fertilizer, and farmyard manure). Fertilizer recommendations based on these models can effectively support 4.0 and 5.0 tons $\mathrm{ha}^{-1}$ yield targets with IPNS components in autumn rice and winter rice, respectively, in humid sub-tropical (Upper Brahmaputra Valley, Assam) north-eastern India, and this site-specific fertilizer recommendation approach proved to be superior to other fertilizer recommendation approaches. Targeted yield fertilizer recommendations provide balanced nutrition to crops and are thus able to sustain crop productivity and soil health. Therefore, applying fertilizers based on site-specific targeted yields may be a useful tool for resource-poor farmers to obtain good profitability with judicious fertilization of nutrients. 
Table 1. Range and mean (2012 and 2013) of soil test values of the farmers' field before the start of the validation trial

\begin{tabular}{cccc}
\hline Parameter* & $\mathrm{N}$ & $\mathrm{P}$ & $\begin{array}{c}\text { Organic C } \\
(\%)\end{array}$ \\
\cline { 2 - 3 } & $\mathrm{kg} \mathrm{ha}^{-1}$ & $\mathrm{~K}$ &
\end{tabular}

\section{Autumn rice}

$\begin{array}{ccccc}\text { Range } & 288.5-351.2 & 6.7-27.7 & 223.1-243.63 & 0.53-1.02 \\ \text { Mean } & 317.2 & 19.5 & 233.6 & 0.72\end{array}$

\section{Winter rice}

\begin{tabular}{ccccc} 
Range & $268.7-346.6$ & $17.9-28.8$ & $108-124.9$ & $0.56-1.12$ \\
Mean & 303.6 & 23.2 & 119.6 & 0.78 \\
\hline
\end{tabular}

* Two year average values

Table 2. Evaluation of the fertilizer recommendation approaches for autumn rice (av. of 8 locations from $2012-$ 2014) and winter rice (av. of 13 locations from 2012-2014) in farmers' fields in humid, sub-tropical (Upper Brahmaputra Valley, Assam) northeastern India

\begin{tabular}{|c|c|c|c|c|c|c|c|c|c|c|}
\hline \multirow[b]{2}{*}{ Treatments } & \multicolumn{3}{|c|}{ Nutrient doses } & \multirow{2}{*}{$\begin{array}{c}\text { Fertilizer } \\
\text { cost } \\
(\mathrm{Rs} / \mathrm{ha})\end{array}$} & \multirow{2}{*}{$\begin{array}{l}\text { Yield } \\
\text { (tons } \\
\left.\mathrm{ha}^{-1}\right)\end{array}$} & \multirow{2}{*}{$\begin{array}{l}\% \\
\text { Achievement } \\
\text { of target yield }\end{array}$} & \multirow{2}{*}{$\begin{array}{l}\text { Yield } \\
\text { cost } \\
(\mathrm{Rs} / \mathrm{ha})\end{array}$} & \multirow{2}{*}{$\begin{array}{l}\text { Additional } \\
\text { yield } \\
\text { advantage } \\
\left(\text { tons ha }^{-1}\right)\end{array}$} & \multirow{2}{*}{$\begin{array}{c}\% \text { Yield } \\
\text { advantage }\end{array}$} & \multirow{2}{*}{$\begin{array}{c}\mathrm{P}=0.01 \text { Additional } \\
\text { profit } \\
(\mathrm{Rs} \cdot / \mathrm{ha})\end{array}$} \\
\hline & $\mathrm{N}$ & $\mathrm{P}_{2} \mathrm{O}_{5}$ & $\mathrm{~K}_{2} \mathrm{O}$ & & & & & & & \\
\hline Autumn Rice & & & & & & & & & & \\
\hline Tl- Farmers' practice & 20 & - & - & 311 & 1.61 & - & 19320 & - & - & - \\
\hline T2- State recommendation & 40 & 20 & 20 & 1542 & 2.24 & - & 26892 & 0.63 & 39 & 7572 \\
\hline T3- Yield target $3 \mathrm{t} \mathrm{ha}^{-1}$ & 21 & 38 & 11 & 2025 & 3.05 & 102 & 36540 & 1.44 & 89 & 17220 \\
\hline T4- Yield target $4 \mathrm{t} \mathrm{ha}^{-1}$ & 88 & 53 & 57 & 3769 & 4.06 & 101 & 48660 & 2.45 & 152 & 29340 \\
\hline $\begin{array}{l}\text { T5- Yield target } 3 \mathrm{t} \mathrm{ha}^{-1}+\mathrm{FYM} \\
5 \mathrm{t} \mathrm{ha}^{-1}\end{array}$ & 16 & 37 & 8 & 1900 & 3.16 & 105 & 37956 & 1.55 & 96 & 18636 \\
\hline $\begin{array}{l}\text { T6- Yield target } 4 \mathrm{tha}^{-1}+\text { FYM } \\
5 \mathrm{t} \mathrm{ha}^{-1}\end{array}$ & 83 & 51 & 53 & 3600 & 4.23 & 106 & 50712 & 2.62 & 162 & 31392 \\
\hline Winter Rice & & & & & & & & & & \\
\hline T1- Farmers' practice & 30 & - & - & 467 & 2.32 & - & 27840 & - & - & - \\
\hline T2- State recommendation & 60 & 20 & 40 & 1873 & 3.35 & - & 40200 & 1.03 & 44 & 12360 \\
\hline T3- Yield target $5 \mathrm{t} \mathrm{ha}^{-1}$ & 19 & 27 & 37 & 1538 & 5.04 & 101 & 60480 & 2.72 & 117 & 32640 \\
\hline T4- Yield target $6 \mathrm{tha}^{-1}$ & 100 & 63 & 74 & 4410 & 5.73 & 96 & 68760 & 3.41 & 147 & 40920 \\
\hline $\begin{array}{l}\text { T5- Yield target } 5 \mathrm{t} \mathrm{ha}^{-1}+\mathrm{FYM} \\
5 \mathrm{t} \mathrm{ha}^{-1}\end{array}$ & 16 & 24 & 29 & 1353 & 5.31 & 106 & 63720 & 2.99 & 129 & 35880 \\
\hline $\begin{array}{l}\text { T6- Yield target } 6 \mathrm{tha}^{-1}+\mathrm{FYM} \\
5 \mathrm{t} \mathrm{ha}^{-1}\end{array}$ & 87 & 61 & 67 & 4113 & 5.86 & 98 & 70320 & 3.54 & 153 & 42480 \\
\hline
\end{tabular}

*Yield advantage over farmers' practice.

$\mathrm{P}=0.01$ Additional profits over farmers' practice.

Sale price of produce (grains): @ Rs. 12/- per kg; Cost price of fertilizer $\left(\mathrm{Rs} \mathrm{kg}^{-1}\right) \mathrm{N}-15.55, \mathrm{P}_{2} \mathrm{O}_{5}-43.75, \mathrm{~K}_{2} \mathrm{O}-24.75$ 
Table 3. Basic data and targeted yield precision model for autumn rice and winter rice

\begin{tabular}{|c|c|c|c|c|c|c|c|c|c|c|c|c|}
\hline \multirow{2}{*}{ Crop } & \multicolumn{3}{|c|}{$\begin{array}{l}\text { Nutrient requirement } \\
\text { (kg/100 kg grain) }\end{array}$} & \multicolumn{3}{|c|}{$\begin{array}{l}\text { Nutrient contribution } \\
\text { from soil }(\%)\end{array}$} & \multicolumn{3}{|c|}{$\begin{array}{l}\text { Nutrient contribution } \\
\text { from fertilizer }(\%)\end{array}$} & \multicolumn{3}{|c|}{$\begin{array}{l}\text { Nutrient contribution } \\
\text { from FYM (\%) }\end{array}$} \\
\hline & $\mathrm{N}$ & $\mathrm{P}_{2} \mathrm{O}_{5}$ & $\mathrm{~K}_{2} \mathrm{O}$ & $\mathrm{N}$ & $\mathrm{P}_{2} \mathrm{O}_{5}$ & $\mathrm{~K}_{2} \mathrm{O}$ & $\mathrm{N}$ & $\mathrm{P}_{2} \mathrm{O}_{5}$ & $\mathrm{~K}_{2} \mathrm{O}$ & $\mathrm{N}$ & $\mathrm{P}_{2} \mathrm{O}_{5}$ & $\mathrm{~K}_{2} \mathrm{O}$ \\
\hline Autumn rice & 2.39 & 0.84 & 2.25 & 15.5 & 17.0 & 26.6 & 35.3 & 28.8 & 49.1 & 6.8 & 4.7 & 7.8 \\
\hline Winter rice & 1.82 & 0.33 & 1.94 & 28.5 & 46.2 & 65.4 & 42.3 & 21.2 & 51.5 & 9.9 & 2.7 & 12.2 \\
\hline
\end{tabular}

\section{Targeted Yield Precision Model for Autumn Rice:}

$\mathrm{FN}=6.77 \mathrm{~T}-0.44 \mathrm{SN}-0.17 \mathrm{ON}$

$\mathrm{FP}_{2} \mathrm{O}_{5}=1.46 \mathrm{~T}-0.29 \mathrm{SP}-0.08 \mathrm{OP}$

$\mathrm{FK}_{2} \mathrm{O}=4.58 \mathrm{~T}-0.54 \mathrm{SK}-0.12 \mathrm{OK}$

\section{Targeted Yield Precision Model for Winter Rice:}

$\mathrm{FN}=8.15 \mathrm{~T}-1.28 \mathrm{SN}-0.44 \mathrm{ON}$

$\mathrm{FP}_{2} \mathrm{O}_{5}=1.55 \mathrm{~T}-0.2 .18 \mathrm{SP}-0.13 \mathrm{OP}$

$\mathrm{FK}_{2} \mathrm{O}=3.77 \mathrm{~T}-1.27 \mathrm{SK}-0.24 \mathrm{OK}$

1. FN, $\mathrm{FP}_{2} \mathrm{O}_{5}$ and $\mathrm{FK}_{2} \mathrm{O}$ are the fertilizer levels of $\mathrm{N}, \mathrm{P}_{2} \mathrm{O}_{5}$ and $\mathrm{K}_{2} \mathrm{O}$, respectively, in $\mathrm{kg} \mathrm{ha}^{-1}$.

2. $\mathrm{T}$ is the yield target in tons $\times 10 \mathrm{~kg} \mathrm{ha}^{-1}$.

3. SN, SP and SK are the soil test values for N, P and K, respectively, in their elemental form in $\mathrm{kg} \mathrm{ha}^{-1}$.

4. ON, OP and $\mathrm{OK}$ are $\mathrm{N}, \mathrm{P}_{2} \mathrm{O}_{5}$ and $\mathrm{K}_{2} \mathrm{O}$, respectively in $\mathrm{kg} \mathrm{ha}^{-1}$ from the IPNS component (FYM). 

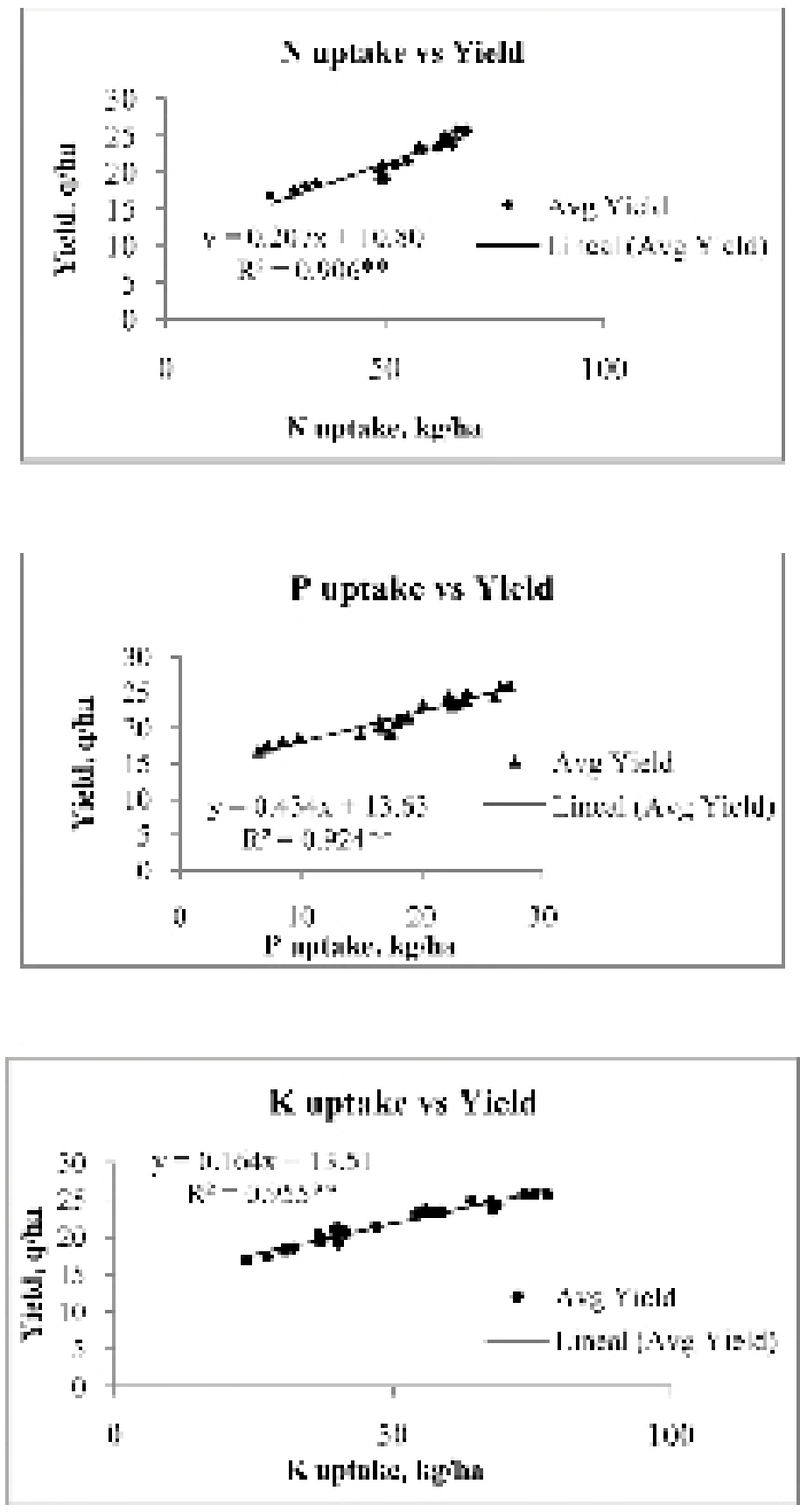

Figure 1. Nutrient Uptake vs Yield of Autumn Rice 

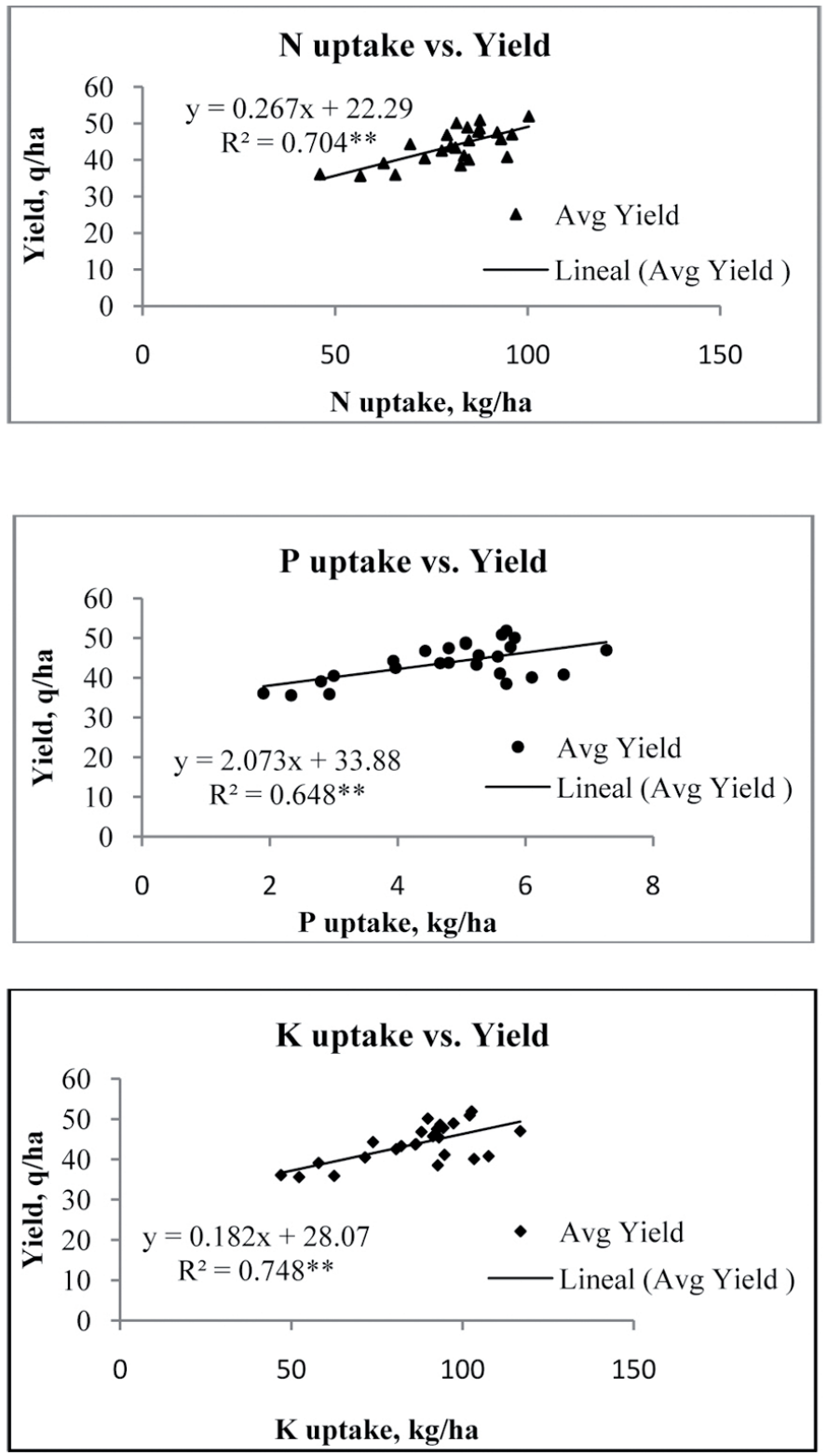

Figure 2. Nutrient Uptake vs Yield of Winter Rice 

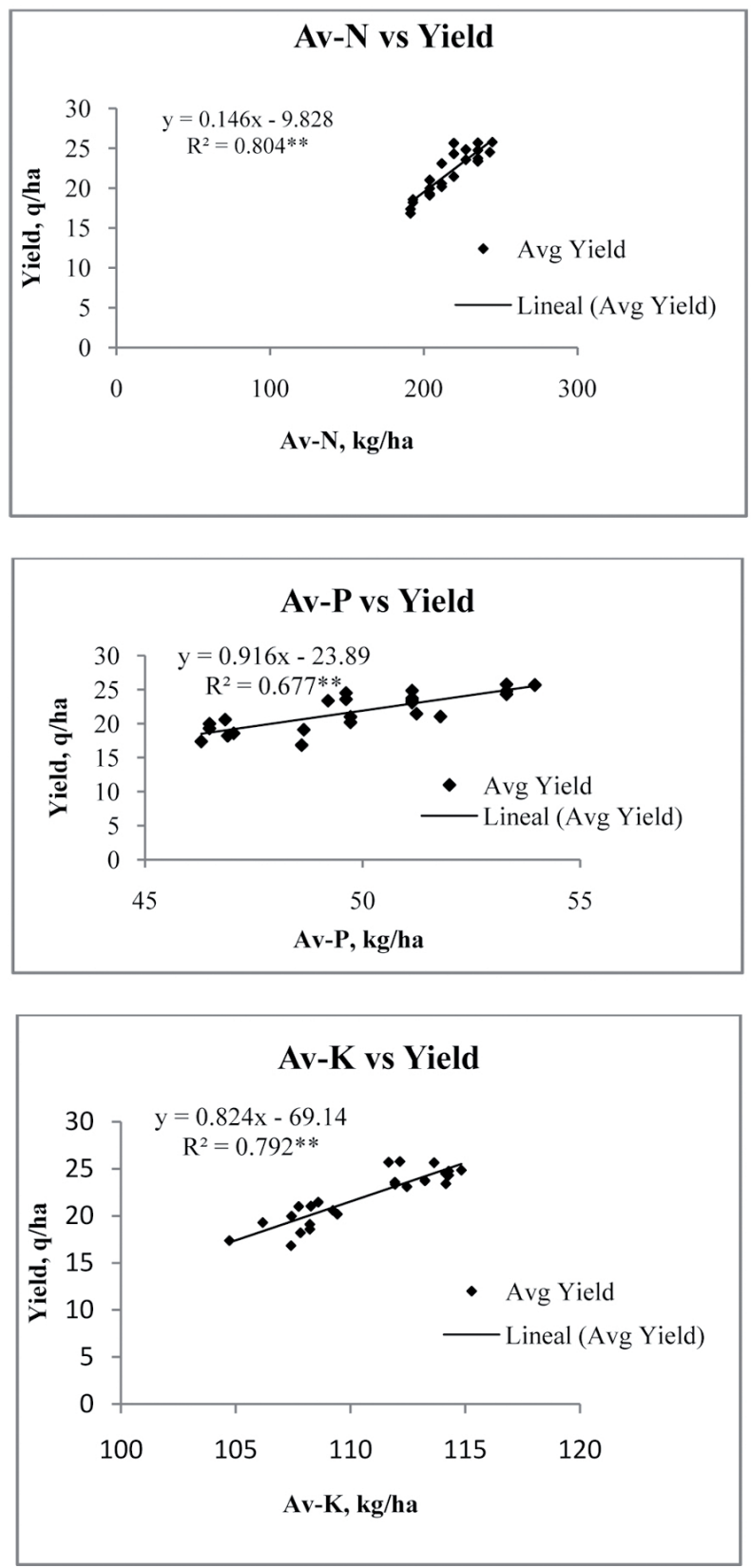

Figure 3. Available Nutrients vs Yield of Autumn Rice 

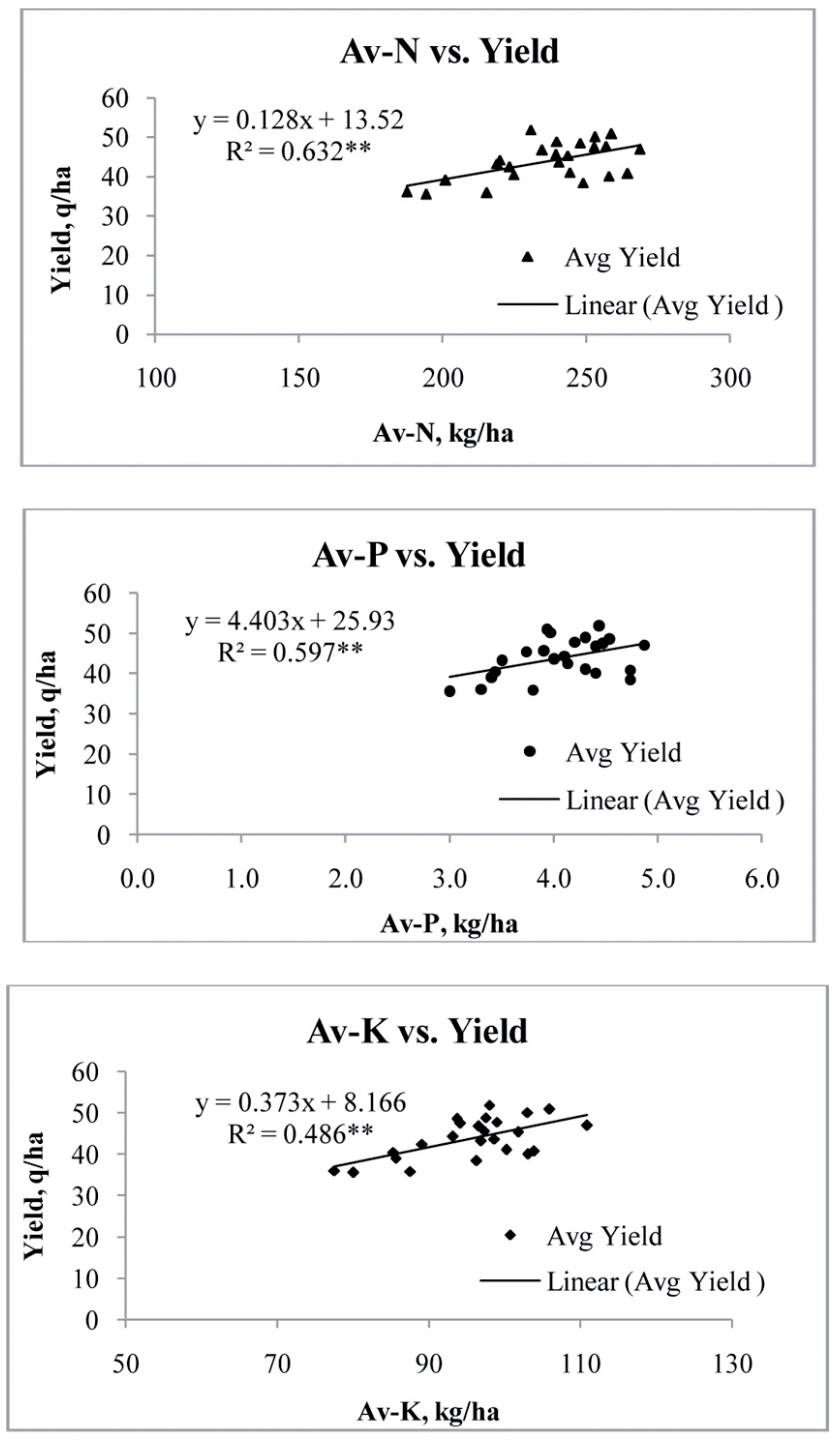

Figure 4. Available Nutrients vs Yield of Winter Rice 


\section{Acknowledgements}

We gratefully acknowledge ICAR in New Delhi and IISS in Bhopal and Assam Agricultural University in Jorhat for funding and implementing the All India Coordinated Research Project for Investigations on Soil Test Crop Response Correlation (AICRP-STCR) at Assam Agricultural University, Assam.

\section{References}

Abolfazli F., Forghani, A., Norouzi, M. 2012. Effects of phosphorus and organic fertilizers on phosphorus fractions in submerged Soil. J. Soil Sci. Plant Nutr. 12(2), 349-362.

Ahmed, S., Riazuddin , M., Krishna Reddy, P.V. 2002. Optimizing fertilizer doses for rice in alluvial soils through chemical fertilizers, farm yard manure and green manure using soil test values. Agropedo. 12, 133-140.

Alfaro V, Marta., Salazar S, Francisco., Endress B, Denisse., Dumont L, Juan., C. Dumont L., Valdebenito B, Aldo. 2006. Nitrogen leaching losses on a volcanic ash soil as affected by the source of fertilizer. J. Soil Sci. Plant Nutr. 6(2), 54-63.

AOAC.1970. Official methods of analysis of the Association of Official Agricultural Chemists. Washington, D.C.: AOAC.

Baldwin, D.S., Mitchell, A.M. 2000. The effects of drying and re-flooding on the sediment and soil nutrient dynamics of lowland river-floodplain systems: a synthesis. Regulated Rivers: Res. Manag. 16, 457-467.

Bera, R., Seal, A., Bhattacharyya, Das, T.H., Sarkar, D, Kangjoo, K. 2006. Targeted yield concept and a framework of fertilizer recommendation in irrigated rice domains of subtropical India. J. Zhejiang Uni. Sci. B. 7, 963-968.
Bhaduri, D., Gautam, P. 2013. Optimization and validation of targeted yield equation-based fertilizer doses under INM for wheat in Tarai region of Uttarakhand, India. Indian J. Agri. Res. $1,16-25$.

Bray, R.H., Kurtz, L.T. 1945. Determination of total, organic, and available forms of phosphorus in soils. Soil Sci. 59, 39-45.

Buresh, R.J., De Datta, S.K. 1991. Nitrogen dynamics and management in rice-legume cropping systems. Adv. Agron. 45, 1-59.

Chacon, N., Dezzeo, N., Munoz, B., Rodriguez, J.M. 2005. Implications of soil organic carbon and the biogeochemistry of iron and aluminum on soil phosphorus distribution in flooded forests of the lower Orinoco River, Venezuela. Biogeochem. 73, 555-566.

Dobermann, A., White, P.F. 1999. Strategies for nutrient management in irrigated and rainfed lowland rice systems. Nutr. Cycl Agroeco. 53(1),1-18.

Dobermann, A., Witt, C., Abdulrachman, S., Gines, H.C., Nagarajan, R., Son, T.T., Tan, P.S., Wang, G.H., Chien, N.V., Thoa, V.T.K, Phung, C.V., Stalin, P., Muthukrishnan, P., Ravi, V., Babu, M., Simbahan, G.C., Adviento, M.A. 2003. Soil fertility and indigenous nutrient supply in irrigated rice domains of Asia. Agron. J. 95, 913-923.

Gayathri, A., Vadivel, A., Santhi, R., Boopathi, P.M., Natesan, R. 2009. Soil test based fertilizer recommendation under integrated plant nutrition system for potato in hilly tracts of Nilgiris district. Indian J. Agri. Res. 43, 52-56.

Ghosh, A., Sharma, A.R. 1999. Effect of combined us of organic manure and nitrogen fertilizer on the performance of rice under flood-prone lowland conditions. J. Agri. Sci. 132, 461-465. 
Jackson, M. L. 1973. Soil Chemical Analysis. Prentice hall of India pvt. Ltd. New Delhi, India

Jai Paul, Suri, V.K., Sandal, S.K., Choudhary, A.K. 2011. Evaluation of targeted yield precision model for soybean and toria crops on farmers' fields under sub-humid, sub-tropical, northwestern Himalayas. Commun. Soil Sci. Plant Anal. 42, 2452-2460.

Kapoor, V., Singh, U., Patil, S. K., Magre, H., Shrivastava, L. K., Mishra, V. N., Das, R. O., Samadhiya, V. K., Sanabria, J., Diamond, R. 2008. Rice growth, grain yield, and floodwater nutrient dynamics as affected by nutrient placement method and rate. Agron. J. 100, 526536.

Katharine, S.P., Santhi, R., Maragatham, S., Natesan, R., Ravikumar, V., Dey, P. 2013. Soil test based fertilizer prescriptions through inductive cum targeted yield model for transgenic cotton on Inceptisol. J. Agri. Vet. Sci. 6, 36-44.

Linquist, B., Sengxua, P. 2003. Efficient and flexible management of nitrogen for rainfed lowland rice. Nutr. Cycl. Agroeco. 67, 107-115.

Ponnamperuma, F.N. 1972. The chemistry of submerged soils, Adv. Agron. 24, 29-96.

Ramamoorthy, B., Velayuthum, M. 1971. Soil-test crop response correlation work in India (World Soil Resources Report No. 41). Rome: F.A.O.

Ramamoorthy, B., Narasimhan, R. L., Dinesh, R. S. 1967. Fertilizer recommendations based on fertilizer application for specific yield of Sonara-64. Indian Farm. 17, 443-451.

Ray, P. K., Jana, A.K., Maitra, D.N., Saha, M.N., Chaudhury, J., Saha, S., Saha, A.R. 2000. Fertilizer prescriptions on soil test basis for jute, rice and wheat in Typic Ustochrept. J. Indian Soc. Soil Sci. 48, 79-84.
Regar, K.L., Singh,Y.V. 2014. Fertilizer recommendation based on soil testing for the targeted yield of rice in eastern plain zone of Utter Pradesh. The Bioscan. 9, 531-534.

Santhi, R., Bhaskaran, A., Natesan, R. 2011. Integrated fertilizer prescriptions for beetroot through inductive cum targeted yield model on an alfisol. Commun. Soil Sci. Plant Anal. 42, 1905-1912.

Santhi, R., Selvakumari, G., Perumal, R. 1999. Soil test based fertilizer recommendations under integrated plant nutrition system for rice- ricepulse cropping sequence. J. Indian Soc. Soil Sci. 47, 288-294.

Saranya, S., Santhi, R., Appavu, K., Rajamani, K. 2012. Soil test based integrated plant nutrition system for ashwagandha on inceptisols. Indian J. Agri. Res. 46, 88-90.

Schnier, H.F. 1995. Significance of timing and method of $\mathrm{N}$ fertilizer application for the $\mathrm{N}$-use efficiency in flooded tropical rice. Fert. Res. 42, 129-138.

Singh, S.R., Maitra, D.N., Kundu, D.K., Majumdar, B., Saha, A. R., Mahapatra, B. S. 2014. Integrated fertilizer prescription equations for recommendations of fertilizers in jute-ricegarden pea sequence on alluvial soil of eastern India. Commun. Soil Sci. Plant Anal. 00, 1-15.

Singh, Y.V., Sharma, P. K., Meena, R. 2014. Effect of soil test crop response technology on productivity and economics of rice crop of Varanasi district of Uttar Pradesh. J. Rural Agr. Res.14, 77-80.

Subbiah, B. V., Asija, G. L. 1956. A rapid procedure for estimation of available nitrogen in soils. Current Sci. 25, 259-260.

Suri, V. K., Verma, T. S., Jai Paul, Sandal, S. K. 2005. Validation of fertilizer adjustment equations based on targeted yield concept for rain-fed soybean grown under wet temperate zone of Himachal Pradesh. Crop Res. 29, 411-415. 
Wade, L. J., Fukai, S., Samson, B.K., Ali, A., Mazid, M. A. 1999. Rainfed lowland rice: physical environment and cultivar requirements. Field Crops Res. 64, 3-12.

Wade, L. J., George, T., Ladha, J. K., Singh, U., Bhuiyan, S.I., Pandey, S. 1998. Opportunities to manipulate nutrient-by-water interactions in rainfed lowland rice systems. Field Crops Res. $56,93-112$.
Witt, C., Dobermann, A., Abdulrachman, S., Gines, H. C., Wang, G. H., Nagarajan, R. Satawathananont, S., Son, T.T., Tan, P.S., Tiem, L.V. 1999. Internal nutrient efficiencies of irrigated lowland rice in tropical and subtropical Asia. Field Crops Res. 63(2), 113-138.

Yin, Y., Liang, C.H. 2013. Transformation of phosphorus fractions in paddy soil amended with pig manure. J. Soil Sci. Plant Nutr. 13(4), 809-818. 